departments of science which experience has shown may be safely dissociated from instruction. Astronomy furnishes an example. Mr. Airy would probably not consider that the teaching of a class would aid him much in his peculiar duties.

We have said that this part of the inquiry will be difficult. The whole inquiry is indeed fraught with difficulty. It means nothing less than the constituting of a department of the State of which even the nucleus cannot be said, as yet, to exist. To do this liberally and efficiently and yet, with such regard to economy as shall make the result visibly beneficial to the community on whom the cost will fall, will be an achievement worthy of any statesman's ambition; but beyond no real statesman's reach.

We do not doubt that the Commission will be granted. Lord de Grey and Mr. Forster are too experienced to attach undue importance to the apparent want of harmony between some of the opinions expressed, or to suppose that all the grounds on which the Commission was asked for could be given in an hour's conversation. They will rather be swayed by the representative character of those who asked for it.

\section{PETROLEUM AND ITS ALLIES}

CONSIDERABLE anxiety has for some time past prevailed as to the existence of danger attending the use, storage and transport of the mineral oil now used for illuminating purposes and, as the questions involved are not only of great importance in many respects; but likely to be soon brought prominently before the public, some account of the sources of mineral oil and of its characteristics will probably be acceptable to our readers.

Thirty years ago, or less, the materials which form the subject of this article were almost unknown to either commerce or manufacturing industry. With some few exceptions, such as the use of the petroleum of Miano, in ltaly, for lighting the streets of Parma and Genoa in 1800 , natural mineral oil was only in scanty demand, under the name of Persian naphtha, for some few minor purposes and it was generally rare, even as a curiosity, in mineralogical collections. The analogous oils obtained artificially, by the distillation of coal and other bituminous materials, were even less famiiiar; for no material was then known that would yield them in sufficiently abundant proportion to admit of their being manufactured on a commercial scale. For this reason mainly, the various attempts to produce such oil were a succession of failures commercially and it was not until about the year 1840 that Mr. James Young, of Glasgow, had the good fortune to meet with a peculiar bituminous mineral-the precise character of which has been the occasion of much controversy-capable of yielding a very much larger proportion of oil by distillation than any other material of a similar kind. The discovery of this material and the recognition of its oil-yielding capability, were speedily turned to account by Mr. Young and his colleagues, forming the basis of a manufacture that has now assumed gigantic proportions and furnishing a commodity which is, for many thousands of people, a daily necessary.

But scarcely had this paraffin oil, now so well known, begun to come into general use as an illuminating material, than a formidable competitor appeared in the market in the shape of natural mineral oil, derived, at first and for a brief period, from Burmah and subsequently, in overwhelming abundance, from certain districts of North America, chiefly Pennsylvania and Canada. Since the first working of the petroleum deposits of America-about the year 1860 , the exportation of this material, or of products manufactured from it, has increased rapidly and it now amounts to little less than one hundred million gallons a year.

The character of the refined petroleum imported from America has had much infuence in extending its use; for, its pleasing appearance and comparative freedom from disagrecable smell, have gained for it a popular preference that so far is not unfounded.

American petroleum, however, contains a large proportion of à very volatile oil or spirit and, consequently, since the introduction of American refined petroleum into the market, the greater part of the oil derived from that source has been characterised by a greater degree of inflammability than the oil manufactured from Rangoon petroleum and from coal or shale; this difference being due to the fact that the volatile spirit, so abundant in American petroleum, is not completely separated in the process of refining. By leaving this spixit in the refined oil, a larger procluce is obtained by the manufacturer and there is a further advantage gained in this way, owing to the fact that the volatile spirit, when separated, generally sells for only half the price of lamp oil.

The practical question in regard to the safety of mineral oil and its fitness for domestic use, is as to the extent to which the more volatile portions of the crude materials should be separated in the refining operation. Although in reference to this question, the possibility of careless and improper usage of the oil cannot reasonably be regarded as justifying any considerable restrictions in the application of a material so useful; still some allowance requires to be made even for that possibility, taking into account the conditions under which mineral oil is carried, stored and used in a general way. The point to be ascertained is not merely what oil may be used without necessary danger ; but what description of oil will best answer the purposes for which it is intended, without requiring a greater degree of caution in its use than can fairly be expected, or any unreasonable restriction on the trade. Hence it would seem to be desirable for the convenience of those engaged in the mineral oil trade, as well as for ensuring public safety, that every branch of this trade should be subject to appropriate regulation: that the degree of inflammability of mineral oil should be limited; a definite standard established and, a mode of testing the oil adopted, which would not admit of discrepant results being obtained, either by accident or otherwise.

With this general object an Act of Parliament "for the Sare Keeping of Petroleum " was passed in 1862, prohibiting the storage of more than forty gallons of petroleum within fifty yards of a dwelling-house or building in which goods were stored, except in virtue of a license granted by local authorities who had the power to annex to their licenses any conditions thought necessary for diminishing risk of damage by fire or explosion. The application of the term "petroleum" in this Act was specially limited to crude petroleum, or any product of it giving off infammable vapour at a temperature less 
than $100^{\circ}$ Fahr. This Act may be said to have been entirely without effect on the refined petroleum sold for use in lamps and, another Act, passed in 1868 to amend it, has been but little more effective in this respect; so that the facts as to the storage and sale of mineral oil, of ail degrees of infammability, remain much the same as they were before.

The abortive character of this Act is probably to be ascribed, in great measure, to a conflict of interests, supposed to be opposite, when the bill was before Parliament and a further reason for its inoperative character, consists in the absence of any sufficient or fitting organisation for carrying out its provisions and regulating the trade in mineral oil. Strange to say, the licensing bodies have, generally speaking, no power under the Act to inspect and test mineral oil, except as a condition of licenses granted by them and the persons who are specially authorised by the Act to inspect and test, are not in most cases under the control of the licensing bodies. Of still greater influence in nullifying the provisions of the Petrolenm Acts, is the want of any properly-constituted authority for instituting proceedings in cases where those provisions have been infringed. Any person may prosecute ; but, as is generally the case with a duty so general, everyone leaves it for some one else to do so.

But perhaps one of the chief reasons why the Petroleum Act of 1868 , has proved inoperative, is to be found in the unsatisfactory nature of the test by which the fitness of mineral oil for domestic use is directed to be ascertained and in the vague terms by which the operation of testing is described in the schedule appended to the Act. The point to be ascertained is the temperature at which mineral oil gives off inflammable vapour and, since any danger that may arise in this way, would exist chiefly in the ordinary use of the oil in lamps, it would seem to be an obvious necessity that the test, applied to ascertain that point, should be conducted under conditions as nearly resembling those obtaining in the actual use of the oil as could possibly be devised. The Act, however, prescribes a test under conditions which are the direct opposite of these. In using a mineral oil lamp, the oil is heated in a closed vessel partly filled with air ; in testing the oil it is directed to be heated in an open vessel with the surface of the oil freely exposed to the atmosphere. In the test, any vapour that is given off from the oil is liable to be blown away by draughts and by diffusing into the surrounding air, to become so much diluted as to lose its inflammable character; while, in the lamp, any vapour given off is confined and forms an explosive mixture with the limited quantity of air contained in the oil reservoir. There is indeed, generally speaking, little real danger attending such a result as this, for the quantity of inflammable vapour produced in the reservoir of a lamp would rarely be sufficient to cause any dangerous explosion; but the flash resulting from the ignition of this vapour, would certainly be enough to startle almost any persons and cause them to drop the lamp. It is probably in this way that many of the accidents with mineral oil have taken place, since the lamps are very generally made of glass and since the oil readily takes fire when spilt upon linen, paper, or any such material.

Besides this cardinal defect in the prescribed test of mineral oil, the various directions given for conducting it are so vague and general, that they leave much to the fancy and option of the operator. Moreover, it is to be doubted whether inspectors of weights and measures, who are the persons authorised under the Act to test mineral oil, are generally competent to conduct these tests in a satisfactory manner.

Although the Act has been in operation only a few months, it has already given rise to much difficulty and inconvenience, without being productive of any benefit. Within the last few weeks, a series of trials of mineral oil, purchased indiscriminately at shops in various parts of the metropolis, has brought to light the fact that, out of 75 samples thus obtained, 39 of them were below the legal standard in regard to inflammability, when tested in strict accord with the directions of the Act.

These facts are sufficient to show that there is great need of further legislative action in this matter; this need has long been felt by those engaged in the mineral oil trade and there is every reason to believe that a welldigested enactment, providing for the safe transport, storage and use of mineral oil, would be of great benefit, not only to the public at large; but also to those engaged in all branches of the trade connected with this useful commodity.

\section{HOSPITAL CONSTRUCTION}

An Adctress on the General Principles which should be Observed in the Construction of Hospitals. Delivered to the British Medical Association at Leeds, by Douglas Galton, C.B., F.R.S. (London: Macmillan and Co., I869.)

THIS able address with the discussion which followed it, brings fully before us the question of hospital construction. The Address itself is exclusively practical: it goes direct to its object and, by appealing to the results of every day's experience of the benefit of cleanliness, space and fresh air ; it points out how these essential elements in the management of the sick, have been embodied in recent hospitals and it indicates by implication, what errors should be avoided.

After stating briefly the work done in this matter by different Sanitary commissions in this country, Mr. Galton gives the following enumeration of objects which must be attained in hospital buildings :-

"I. Pure air, that is to say, there should be no appreciable difference between the air inside the ward and that outside the building.

"2. The air supplied to the ward should be capable of being warmed to any required extent.

"3. Pure water, so supplied as to ensure the removal of all impurities to a distance from the hospital.

"4. The most perfect cleanliness within and around the building."

To realise these conditions the first step in hospital improvement is to select healthy sites, away from irremovable sources of air impurity and, having by this means obtained a pure moving atmosphere, the author proceeds to show how the site is to be used so that the pure atmosphere may not become a disease generator in the wards. The building must be so arranged as to interfere as little as possible with the free, natural movement of the outer air and this free outside movement should be kept up, as far as practicable, within the wards. "Stagnant air is foul air," especially in a hospital. 